\title{
THE EFFECTIVENESS OF MINI-CEX ASSESSMENT TOOL FOR CLINICAL COMPETENCY ACHIEVEMENT IN CLINICAL PRACTICE AMONG ANESTHESIA TRAINEE.
}

1. MBBS, FCPS Anesthesia, FCPS (Cardiothoracic Anesthesia) Assistant Professor Anesthesia and Intensive Care

Ch. Pervaiz Ellahi Institute of Cardiology, Multan

2. MBBS

House Officer Anesthesia and Intensive Care

Nishtar Hospital Multan

3. MBBS

House Officer Anesthesia and Intensive Care

Nishtar Hospital Multan.

4. MBBS, FCPS

Consultant Pulmonologist Intensive Care

Ch. Pervaiz Ellahi Institute of Cardiology.

5. MBBS, FCPS

Consultant Gynecologist Nishtar Hospital Multan.

6. BSC (Hon)

Medical Emergency Technologist

DHQ Hospital Khanewale.

Correspondence Address:

Dr. Aamir Furqan

Assistant Professor Anesthesia and Intensive Care.

Ch. Pervaiz Ellahi Institute of

Cardiology, Multan.

draamir2009@hotmail.com

Article received on:

27/03/2019

Accepted for publication:

25/05/2019

\section{INTRODUCTION}

The module of program in anesthesia training has experienced a shift from discipline-based education to proficiency-based education. The aptitude rooted curriculum in anesthesia trainee education amounts to $60 \%$ focus of clinical application based out of its overall credits. ${ }^{1}$ Hence, this sort of variation demands amendments in learning practice together with assessment process. Seemingly, it has been found troublesome for anesthesia trainee to adapt skillful abilities during the course of clinical internship program. ${ }^{2}$ Such limitations can bring about deficiency in acquiring clinical proficiency as a skillful anesthetist according to the approved standards in anesthesia education. ${ }^{3}$

\begin{abstract}
Aamir Furqan', Azeem Gulzar ${ }^{2}$, Bilal Nazar ${ }^{3}$, Masood Alam ${ }^{4}$, Rahat Akhtar ${ }^{5}$, Farman Ali ${ }^{6}$ Design: Prospective Observational Study. Setting: Department of Anesthesia and Intensive Care Ch. Pervez Ellahi Institute of Cardiology and Nishtar Hospital Multan. Period: January 2017 to March 2019. Material \& Methods: The design of study was prospective observational in the control group whereas 35 trainee were part of the intervention group. The analysis of data was done by Mann Whitney test and it was descriptive type of test. Results: The mean result of Preoperative examination skills among the intervention group was greater than the control group. The mean score of Preoperative examination competence in control group was (2.11 \pm 4.56, while the mean score of Preoperative examination competence in intervention control and intervention group was $5.37 \pm 0.38$ and $8.95 \pm 0.64$, respectively. While the mean score of evaluators towards satisfaction of control and intervention group was $6.24 \pm 0.53$ and $8.04 \pm 0.52$, respectively. The difference of clinical abilities was significant among the two groups was significantly ameliorated after the use of Mini-CEX program. It is therefore suggested for anesthesia trainers to use the Mini-CEX program in order to determine the clinical skills among
\end{abstract} Key words: $\quad$ Anesthesia Trainee, Clinical Skills, Mini-CEX, Preoperative Examination.

Article Citation: Furqan A, Gulzar A, Nazar B, Alam M, Akhtar R, Ali F. The effectiveness of mini-CEX assessment tool for clinical competency achievement in clinical practice among anesthesia trainee. Professional Med J 2020; 27(2):279283. DOI: 10.29309/TPMJ/2020.27.2.3452

An examination which is performed to determine the clinical skill is known as procedural skill assessment examination. ${ }^{4}$ The expectation from student is such that they are able to perform the practical examination with expert skills. ${ }^{5}$ To fulfill such expectations, it is required that a clinical evaluation is conducted which can also enhance the motivation of students towards learning. ${ }^{6}$

Multiple methods of clinical evaluation in anesthesia training are available for example direct observation, viva voce, journal report, objective examination, mini-CEX, case-based discussion, multisource feedback and many more. The validity of these methods is still being assessed. ${ }^{7}$ Various inconveniences are encountered in each of the above method on part of student and 
examiner as well as the patients. Usually, it's only once that the performance assessment is done, and that too by one examiner only. ${ }^{8}$ There is lack of observation and feedback which does not enable the examiner to determine the benefits or disadvantages of a certain test type.

Multiple benefits of mini-CEX have been observed in evaluation of clinical practice among anesthesia trainee. There is possibility of conducting this program in a number of settings. ${ }^{9}$ It can be performed in different scenarios and clinical cases which increases the exposure of student to perform numerous clinical interventions which in turn enhances the performance of students. ${ }^{10}$ It also provides the clinical examiner with satisfaction by using this tool for evaluation. In this way, the evaluator is able to provide constructive response with regards to students' performance.

The feedback also proves to be a way of guidance in order to correct or improve students' weakness. It implies that the aforementioned benefits of miniCEX enhance the ability of students' learning and improving the strength of healthcare provision to the patients. The evaluation by mini-CEX is done for about 15 minutes when the student is performing a procedure on patient, after that, 5 minutes are spent giving constructive feedback to the students according to their level of performance.

The following study is performed to inquire the variance of students' proficiency evaluation among control and intervention group after the usage of mini-CEX. It is expected that the use of mini-CEX during the course of anesthesia training will improve the clinical proficiency of anesthesia trainees.

\section{MATERIAL \& METHODS}

The mode of study was mock experimental which only used the post-test involving only the control group design. The subjects of study were all anesthesia trainees enrolled in the fellowship program performing the clinical practice in hospital. The sampling was done by using the technique of non probability consecutive sampling. The study took place from January
2017 to March 2019.

The study was performed after obtaining the approval from the institutional Ethics committee. An emphasis was done on various ethical issues such as secrecy and anonymity, self-confidence, benevolence, and integrity. The study was performed at hospital as the anesthesia trainees were based in this hospital. 8 operation rooms were used to perform the study, 4 of them were used for the control group while 4 were used for intervention group. Two procedures were used during the course of this study. One was the air way assessment before general anaesthesia and performing Subarachnoid Block used in the evaluation of clinical practice of anesthesia trainee during their fellowship program. In order to obtain assessment data from control group, rating scale was put into use.

The second tool that was used was the mini-CEX assessment sheet that was formulated by Norcini et al in 2003 that involves the identification of the evaluator and the student and the scale ranges from 1 to 9 . The category of this scale included three types of performances being "superior", "meet expectations", and "remedial". The elements that were assessed by this tool included the intervention strategy, exam performing ability, proficiency in treating the patients. If a student was able to score $\geq 75$ he was categorized as "competent" and if the score was $\leq 75$, he was put into the category of "incompetent". After the completion of evaluation, the satisfaction of student and the clinical evaluator was evaluated regarding the mini-CEX tool and customary assessment method.

SPSS version 24 was used for data analysis, mean and SD was calculated for numerical data and frequency percentages were calculated for qualitative data. Student t-test and chi square test were used to see association among variables. $P$ value $\leq 0.05$ was taken as significant.

\section{RESULTS}

Seventy patients were included in this study, both genders. The patients were further divided into two equal groups i.e. controls $n=35$ (50.0\%) 
and interventions $n=35$ (50.0\%). The mean age of control group was $24.51 \pm 2.44$ years. There was $n=19(54.3 \%)$ males and $n=16 \quad(45.7 \%)$ female. The mean age of intervention group was $23.80 \pm 1.32$ years. There was $n=15(42.9 \%)$ males and $n=20$ (57.1\%) females. (Table-I).

\begin{tabular}{|c|c|c|c|}
\hline \multirow[b]{2}{*}{ Variable } & \multicolumn{2}{|c|}{ Group } & \multirow{2}{*}{$\begin{array}{c}\text { P. } \\
\text { Value }\end{array}$} \\
\hline & $\begin{array}{c}\text { Control } \\
n=35(50 \%)\end{array}$ & $\begin{array}{l}\text { Intervention } \\
n=35(50 \%)\end{array}$ & \\
\hline Age (years) & $24.51 \pm 2.44$ & $23.80 \pm 1.32$ & 0.133 \\
\hline \multicolumn{4}{|l|}{ Gender } \\
\hline Male & $n=19(54.3 \%)$ & $n=15(42.9 \%)$ & \multirow{2}{*}{0.339} \\
\hline Female & $n=16(45.7 \%)$ & $\mathrm{n}=20(57.1 \%)$ & \\
\hline
\end{tabular}

Table-I. Demographic variables of the respondents.

The mean score of Procedural competence in control group was $72.11 \pm 4.56$, while the mean score of Procedural competence in intervention group was $81.28 \pm 2.86$. The mean score of anesthesia trainees towards satisfaction of control and intervention group was $5.37 \pm 0.38$ and $8.95 \pm 0.64$, respectively. While the mean score of evaluators towards satisfaction of control and intervention group was $6.24 \pm 0.53$ and $8.04 \pm 0.52$, respectively. The differences were statistically significant at $(p=0.000)$. (Table-II).

\begin{tabular}{|c|c|c|c|}
\hline \multirow[b]{2}{*}{ Variable } & \multicolumn{2}{|c|}{ Group } & \multirow{2}{*}{$\begin{array}{c}\text { P- } \\
\text { Value }\end{array}$} \\
\hline & $\begin{array}{c}\text { Control } \\
n=35(50 \%)\end{array}$ & $\begin{array}{l}\text { Intervention } \\
n=35(50 \%)\end{array}$ & \\
\hline $\begin{array}{l}\text { Procedural Skill } \\
\text { competence }\end{array}$ & $72.11 \pm 4.56$ & $81.28 \pm 2.86$ & 0.000 \\
\hline $\begin{array}{l}\text { Anaesthesia } \\
\text { Students' } \\
\text { Satisfaction }\end{array}$ & $5.37 \pm 0.38$ & $8.95 \pm 0.64$ & 0.000 \\
\hline $\begin{array}{l}\text { Evaluators' } \\
\text { Satisfaction }\end{array}$ & $6.24 \pm 0.53$ & $8.04 \pm 0.52$ & 0.000 \\
\hline
\end{tabular}

Table-II. Satisfaction criteria of the Respondents.

\section{DISCUSSION}

In our study in intervention group a great number of respondents assure satisfaction over mini-CEX programming. In a study done by Philips SJ et $\mathrm{al}^{11}$, the results demonstrated that regardless of strongly suggestive educational hypothesis and after being used widely in medical education system for many years, there remain a number of problems encountered in the efficacious usage of mini-CEX.

There are various factors that affect the procurement of response to the students after mini-CEX assessment. In a pilot study performed upon final year medical students by Fernando $\mathrm{N}$ et $\mathrm{al}^{12}$, it was evident that those examiners who gave away a broad range of scores with regards to particular expertise field had more chance of recording sections for improvement and plan of action.

However, Suhoyo $Y$ et al reported ${ }^{13}$ a number of challenges are encountered when mini-CEX is implemented in different cultures and regions of the world. This problem can be tackled easily by the careful management of innovation process and considering the local and cultural context. Hence mini-CEX can be applied without the underlying idea being changed. In a study done by Seadon $\mathrm{H}$ et $\mathrm{al}^{14}$ on trainees of New Zealand, a strongly positive academic influence was described. In its written form, 95\% expert categorized mini-CEX under "things that trainee did well.

When Hill $F$ et $\mathrm{al}^{15}$ determined the factors affecting the adopting and the adapting of miniCEX, found out that it must be endorsed with regards to particular settings and local interest. The assessment must be included in the final evaluation of students. Hawkins RE et $\mathrm{al}^{16}$ reported that if the choice of selection is given to the trainees in for their cases and assessors, it is implied to have an effect on the grading outcomes especially with regards to summative evaluation.

Liao $\mathrm{KC}$ et al ${ }^{17}$ concluded that mini-CEX is termed as "valid and reliable" tool in order to determine the clinical proficiency of trainees by. To employ a fruitful mini-CEX evaluation program, it is suggested as a prerequisite to develop the faculty for training the evaluators.

A meta-analysis was performed by Ansari A et $\mathrm{al}^{18}$ in order to determine the "construct and criterion" foundation of mini-CEX to evaluate the clinical performance. The mini-CEX can be used on a daily basis but limited to field of program 
and purpose of evaluation. In conclusion, miniCEX has established to be beneficial in training assessment having clear evidence of construct and criterion validity.

A score analysis done by Jackson $\mathrm{D}$ et $\mathrm{al}{ }^{19}$ showed exceptional reliability data. It is suggested that further research is required in order to ensure the complete utilization and benefits of mini-CEX. Especially, the assessors need proper training if better outcome is desired. Overall, it is believed to be of similar value in terms of measurement characteristics, as those of other skills evaluation procedures. $^{20}$

\section{CONCLUSION}

Clinical expertise among anesthesia trainee was significantly ameliorated after the use of Mini-CEX program. It is therefore suggested for anesthesia trainers to use the Mini-CEX program in order the determine the clinical skills among students.

Copyright@ 25 May, 2019.

\section{REFERENCES}

1. Cook DA, Beckman TJ, Mandrekar JN, Pankratz VS. Internal structure of the mini-CEX for internal medicine residents: Factor analysis and generalizability. Advances in health sciences education: Theory Practice. 2010; 15, 633-645.

2. Kogan JR, Conforti L, Bernabeo E, lobstW, Holmboe E. Opening the black box of clinical skills assessment via observation: A conceptual model. Medical Education. 2011; 45, 1048-60.

3. Pelgrim, E. A. M., Kramer, A. W. M., Mokkinik, H. G. A., Van den Elsen, L., Grol, R. P. T. M., \& Van der Vleuten, C. P. M. In-training assessment using direct observation of single-patient encounters: A literature review. Advances in health science education: Theory and Practice. 2011; 16, 131-142.

4. Ahmed K, Miskovic D, Darzi A, Athanasiou T, Hanna GB. Observational tools for assessment of procedural skills: a systematic review. Am J Surg. 2011; 202(4):469-80.

5. Sandilands D, Zumbo BD. (Mis) Alignment of medical education validation research with contemporary validity theory: The Mini-CEX as an example. In: Zumbo B., Chan E. (eds) Validity and Validation in Social, Behavioral, and Health Sciences. Social Indicators Research Series. Cham: Springer. 2014; 54:289-310.
6. Naeem N. Validity, reliability, feasibility, acceptability and educational impact of direct observation of procedural skills (DOPS). J Coll Physicians Surg Pak. 2013; 23(1):77-82.

7. Donato AA, Pangaro L, Smith C. Evaluation of a novel assessment form for observing medical residents: A randomized, controlled trial. Med Educ. 2008; 42:1234- 1242.

8. Clauser BE, Margolis MJ, Swanson DB. Issues of validity and reliability for assessments in medical education. In: Holmboe ES, Hawkins RE, eds. A practical guide to the evaluation of clinical competence. Philadelphia, Pa: Elsevier; 2008:10-23.

9. Cook DA, Beckman TJ. Does scale length matter? A comparison of nine- versus five point scales for the mini-CEX. Adv Health Sci Educ Theory Pract. 2009; 14:655-664.

10. Cook DA, Dupras DM, Beckman TJ, Thomas KG, Pankratz $S$. Effect of rater training on reliability and accuracy of mini-CEX scores: A randomized, controlled trial. J Gen Intern Med. 2008; 24:74-79

11. Weston PS, Smith CA. The use of mini-CEX in UK foundation training six years following its introduction: lessons still to be learned and the benefit of formal teaching regarding its utility. Med Teach. 2014; 36(2):155-63.

12. Fernando N, Cleland J, McKenzie $H$, Cassar K. Identifying the factors that determine feedback given to undergraduate medical students following formative mini-CEX assessments. Medical education. 2008; 42(1): 89-85.

13. Suhoyo Y, Schonrock J, Rahayu GR, Jan BM, Cohen J. Meeting international standards: A cultural approach in implementing the mini-CEX effectively in Indonesian clerkships. Medical education. 2014; 36: 894-902

14. Seadon H, Salleh S, Balakrishnan A, Imray C, Seadon M. The role of feedback in improving the effectiveness of workplace-based assessments: A systematic review. BMC Medical Education. 2012; 12:25.

15. Hill F, Kendall K. Adopting and adapting the mini-CEX as an undergraduate assessment and learning tool. The clinical teacher. 2007; 4: 244-248.

16. Hawkins RE, Margolis MJ, Durning SJ, Norcini JJ. Constructing a validity argument for the mini-clinical evaluation exercise: A review of the research. Academic Medicine. 2010; 85(9). 
17. Liao KC, Pu SJ, Liu MS, Yang CW, Kuo HP. Development and implementation of a mini-Clinical Evaluation Exercise (mini-CEX) program to assess the clinical competencies of internal medicine residents: from faculty development to curriculum evaluation. BMC Medical Education. 2013; 13:31.

18. Ansari A, Ali S.K, Donnon T. The construct and criterion validity of the mini-cex: a meta-analysis of the published research. Acad Med. 2013; 88:413-420.
19. Jackson D. An evaluation of the use of the miniCEX in the foundation program. British Journal of Hospital Medicine. 2010; 71(10).

20. Norcini JJ, Blank LL, Duffy FD, Fortna GS. The MiniCEX: A method for assessing clinical skills. Annals of Internal Medicine. 2003; 138, 476-481.

\begin{tabular}{|c|c|c|c|}
\hline \multicolumn{4}{|c|}{ AUTHORSHIP AND CONTRIBUTION DECLARATION } \\
\hline Sr. \# & Author(s) Full Name & Contribution to the paper & Author(s) Signature \\
\hline 1 & Aamir Furqan & $\begin{array}{l}\text { Conceived idea, Study } \\
\text { design. }\end{array}$ & \\
\hline 2 & Azeem Gulzar & $\begin{array}{l}\text { Data collection, Literature } \\
\text { review. }\end{array}$ & \\
\hline 3 & Bilal Nazar & $\begin{array}{l}\text { Manuscript writing, Data } \\
\text { analysis. }\end{array}$ & \\
\hline 4 & Masood Alam & $\begin{array}{l}\text { Study design, Literature } \\
\text { review. }\end{array}$ & \\
\hline 5 & Rahat Akhtar & $\begin{array}{l}\text { Manuscript writing, Data } \\
\text { analysis. }\end{array}$ & $\perp_{a}$ \\
\hline 6 & Farman Ali & $\begin{array}{l}\text { Statistical Analysis, Final } \\
\text { Proof Reading. }\end{array}$ & \\
\hline
\end{tabular}

